\title{
A fortuna crítica de Gilberto Freyre
}

Edson Nery da Fonseca

\section{INTRODUÇÃO: GILBERTO FREYRE E O RIO DE JANEIRO}

Agradeço a Bruno Barreto Gomide o convite para inaugurar o ciclo de palestras A PROPÓSITO DE GILBERTO FREYRE, título feliz porque muito freyriano. Um dos paradoxos de Gilberto Freyre é que tendo sido ele confessadamente vaidoso, ao abordar qualquer assunto assumia uma postura de humildade científica, pois considerava, como disse numa conferência de 1940, que "a verd adeira ciência é humilde, ficando a ênfase para a meia-ciência" 1. Como autêntico ensaísta, evitava o estilo tratadístico através de locuções como "a propósito de" ou "em torno de" e de palavras como "contribuição", "sugestões" e "introdução", todas muito freqüentes nos títulos de seus ensaios.

Permito-me interpretar a iniciativa do Centro Cultural Banco do Brasil como uma homenagem de todo o Rio de Janeiro a um escritor que, tendo nascido no Recife, muito amou esta bela cidade. Não sei se diga que amou o Brasil acima de tudo porque, para ele, o Brasil era tanto um complexo transregional de ilhas ecológica e culturalmente diversas como uma integração continental de cidades. E o Rio de Janeiro era uma das cinco cidades brasileiras que mais amava e para as quais desejou escrever guias práticos, histór icos e sentimentais, um gênero de livro por ele inventado. Para o do Rio de Janeiro até já dispunha de ilustrações: desenhos e pinturas de Maria Retchek, uma senhora austríaca que fora ministra de seu país no Brasil. 
Foi em março de 1926 que Gilberto Freyre conheceu o Rio de Janeiro e logo registrou seu alumbramento no artigo "Sugestões do Rio". É verdade que os horrores da arquitetura o chocaram. Pareceram-lhe borrões. Mas a forte e até escandalosa beleza da pa isagem como que os sugava ou chupava "atenuando-os, disfarça ndo-os com a indulgência maternal de um mata-borrão". Era o p oeta a se valer da imagem para exprimir o contraste realmente ch ocante das curvas graciosas das praias e dos montes cariocas com os edifícios incaracterísticos do começo do século. Dentre esses edif ícios avultava, pela feiúra, o incrível Palácio Tiradentes, do qual e screveu naquele artigo de 1926: "Parece-me, ainda, mentira o que vi. É verdadeiramente assombroso. Um monstro". 2

Infelizmente, Gilberto Freyre não teve tempo ou veneta para escrever os guias práticos, históricos e sentimentais do Rio de Janeiro, da Bahia e de Belém do Pará. Publicou apenas os do Recife e de Olinda, duas obras-primas de paisagismo lírico. ${ }^{3}$ Como também não chegou a escrever Jazigos e Covas Rasas, nem Um Brasileiro na Espanha, nem Um Homem no Meio de um Século, nem À Procura de um Menino Perdido e vários outros livros anunciados. Para concretizar todos os seus projetos literários teria de viver muito mais do que os oitenta e sete anos e quatro meses de sua "vida de aquém-túmulo", para citar a boutade rosiana.

Como não conseguia escrever o guia prático, histórico $\mathrm{e}$ sentimental do Rio de Janeiro, Gilberto Freyre passou a tarefa a seu grande amigo Gastão Cruls, autor de Aparência do Rio de Janeiro, publicado em 1949. O prefácio de Freyre a esse livro de Cruls é uma interpretação psicoantropológica da geografia urbana do Rio de Janeiro. Fala nas saliências dos morros "sempre jovens em sua vegetação" e em contraste com "arranha-céus estandardizadores". Imagista genial, compara as "formas dos morros em que a pais agem da cidade parecia arredondar-se" a "ventres de mulheres moças à espera de arquitetos, de artistas, de homens que as soubessem 
fecundar". E refere-se ao relacionamento íntimo, profundo, exi stencial da cidade com o mar: relacionamento responsável pelo c aráter lúdico do carioca, definido como um "quase anfíbio", pois "regala-se dágua do mar e de vida de praia como outrora os indíg enas se regalavam dágua dos rios". ${ }^{4}$

\section{FORTUNA CRÍTICA E RECEPÇÃO}

A palavra "fortuna" significa causalidade, eventualidade, ac aso; e também destino, fado, sorte. Tem ainda, como é sabido, o utras acepções, mas foi assim que Camões a empregou numa de suas Rimas: "Erros meus, má fortuna, amor ardente / em minha perd ição se conjuraram". Críticos italianos costumam designar como "fortuna" a repercussão que um escritor ou uma obra obtiveram tanto entre os contemporâneos como em gerações sucessivas.A fortuna de um autor ou de uma obra pode ser estudada pela ch amada curva das edições, pelas traduções, adaptações, imitações, avaliações e também pela influência literária ou espiritual que exe rceram.

Em língua portuguesa o fenômeno tornou-se conhecido pela expressão "fortuna crítica" e, mais recentemente, pela palavra "recepção", suscitada pela teoria da comunicação literária, de aco rdo com a qual o autor é o emissor e o leitor o receptor da mens agem.

\section{LIMITES DO ASSUNTO}

Não é a primeira vez que procuro abordar o assunto. ${ }^{5} \mathrm{E}$, como sempre, vejo-me na obrigação de ser seletivo. Porque a extensa e variada obra freyriana, produzida em mais de meio século de incursões do autor por quase todas as áreas do saber científico e humanístico, suscitou centenas de textos, favoráveis e desfavorá- 
veis, divulgados sob a forma de livros, prefácios, contribuições em obras coletivas, artigos de revista e jornal.

Para ser exaustivo, teria de ultrapassar os limites razoáveis de uma conferência, o que não faço por questão de princípio: por considerar, como meu amigo de Harvard Joaquim-Francisco Co elho, que ninguém é interessante depois de 40 minutos.

Serei, portanto, rigorosamente seletivo, o que é, aliás, muito mais difícil do que ser exaustivo. É como a história dos sermões encomendados a um grande orador sacro: quanto menor a exte nsão, maior a espórtula cobrada.

As bibliografias exaustivas deixaram de ter sentido com a explosão bibliográfica de nossa época. $\mathrm{O}$ que os pesquisadores querem saber não é tudo o que foi escrito sobre determinado autor ou assunto, e sim as contribuições originais e o estado atual da fortuna crítica: em francês état de la question, em inglês state-ofthe-art, em alemão Literaturbericht.

Além de seletivo, vou limitar-me ao período 1933-1983, que perfaz o número redondo de 50 anos: meio século de fortuna crít ica freyriana. Não é um limite arbitrário. Além de assinalar o cinqüentenário de Casa-Grande \& Senzala, 1983 foi o ano em que Gilberto Freyre publicou seu último livro importante: Insurgências e Ressurgências Atuais ${ }^{6}$ Dos seis livros posteriores, três são produtos de uma criatividade já fatigada - Homens, Engenharias e Rumos Sociais (1987), Modos de Homem \& Modas de Mulher (1987) e Ferro e Civilização no Brasil (1988) - e os demais são coletâneas póstumas de textos dispersos: Bahia e Baianos (1990), Discursos Parlamentares (1994) e Novas Conferências em Busca de Leitores (1995). Insurgências e Ressurgências Atuais é uma espécie de balanço que o autor faz de sua obra, mostrando-se atualíssimo em relação aos problemas do Brasil e do mundo e assim deixando desnorteados os que o acusavam de pa ssadista. 


\section{A CRÍTICA DOS ANOS 30}

Quando Casa-Grande \& Senzala apareceu, no início da década de 1930, a crítica literária brasileira encontrava-se numa de suas fases mais brilhantes. Os grandes jornais mantinham rodapés hebdomadários, assinados por conceituados escritores. No Jornal do Brasil pontificava João Ribeiro, "o tipo exemplar do humanista moderno, a quem não faltava nunca o grão de sal da heresia", como o definiu Alfredo Bosi. ${ }^{7}$ Depois de escrever obras de indiscutível importância filológica, histórica, estética e folclórica, João Ribeiro, que pertencia à geração dos parnasianos, passou a exercer a crítica hebdomadária com inusitada receptividade aos escritores mais novos e às correntes de vanguarda. Era, como o classificou Álvaro Lins, ao mesmo tempo "clássico e moderno". 8

O que disse João Ribeiro de Gilberto Freyre, quarenta anos mais moço do que ele? Que não sabia de "outro brasileiro que com tanta acuidade nos observasse". E assinalou pioneiramente que

Casa-Grande \& Senzala "não conclui": para ele, não um defeito, mas uma virtude. "É um livro de nunca acabar, -- escreveu - como certos contos folclóricos sem fim". 9

Mais moço do que João Ribeiro, Agripino Grieco foi outro humanista que levou para a crítica literária hebdomadária a enorme erudição comprovada por sua imensa biblioteca, adquirida postmortem pela Universidade de Brasília. Jamais esquecerei de minha emoção ao adentrar a casa do Méier para dar parecer sobre a aqu isição proposta pelos filhos de Grieco. Ali estavam todas as literat uras do mundo. Aquele homem poderia ter dito, como Mallarmé, que lera "todos os livros": La chair est triste, hélas! Et j’ai lu tous les livres.

Temido pelo sarcasmo com o qual invectivava os pomposos acadêmicos da época, era receptível tanto aos valores que despont avam após a revolução modernista quanto ao misticismo que o levara 
a escrever, em 1935, um belo ensaio sobre São Francisco e a Poesia Cristã. Agripino Grieco exercia a crítica literária em O Jornal do Rio de Janeiro. Ele começa seu longo artigo sobre Casa-Grande \& Senzala dizendo que para analisar conscientemente a obra "seria necessário documentar-se tanto quanto seu autor". Reclama as "r epetições ou pequenas incoerências", mas qualifica o livro como "notabilíssimo" e "sutilíssima obra de arte". Define Gilberto Freyre como "um Oliveira Lima descarnado e ágil que se esgueira lepidamente por entre citações e transcrições e não dá nunca a sensação de carreto histórico". Depois de muitos comentários nos quais demonstra sua enorme cultura, Grieco conclui: "Está aqui uma espécie de história do Brasil, contada inteligentemente, à moderna, com grande amenidade. Interpretação por vezes demasiado materialista, com um pouco de rudeza e sequidão científicas, não exclui, de modo algum, certos trechos de irresistível efusão poética. Talvez falte ao autor um núcleo, um centro, e há muita coisa lateral no livro.Talvez lhe falte uma 'convicção'. Mas, com todos os defeitos, será necess ário repetir que se trata de uma obra notabilíssima?" 10

Plínio Barreto, outro veterano sensível aos estreantes, mant inha a seção de "Livros Novos" em O Estado de S. Paulo. Político, advogado e jornalista militante, Plínio Barreto faz uma análise longa e penetrante de Casa-Grande \& Senzala. Elogia as "páginas curiosíssimas e cheias de ensinamento", esclarecendo, entretanto, que não eram recomendáveis "a todos os leitores", porque "o sr. Gilberto Freyre gosta de dizer as coisas nua e cruamente", escrevendo "em português claro aquilo que os autores pudicos costumavam escrever em latim..."11

Dentre os jovens que se iniciavam nas letras como críticos merecem destaque Lúcia Miguel Pereira na Gazeta de Notícias do Rio de Janeiro e Afonso Arinos de Melo Franco em O Jornal. Lúcia jả estreara, em 1930, com os romances Maria Luisa e Em Surdina; e se consagraria depois como ensaísta e biógrafa. Ela já escreve s o- 
bre Casa-Grande \& Senzala em outubro de 1934 e reclama maior consagtação para o livro, que deveria "andar em todas as mãos" porque alarga "no tempo, os limites de uma nação. Chama Gilberto Freyre "escritor de raça", mas critica-o porque "sacrifica uma ou outra vez ao ídolo moderno do relaxamento verbal, mas logo volta à boa linguagem". Ao contrário de outros críticos, Lúcia Miguel Pere ira encontra conclusões em Casa-Grande \& Senzala: conclusões que Freyre "faz ressaltar de uma doc umentação honesta, sem partipris, sem pressa de generalizar". ${ }^{12}$

Como Lúcia Miguel Pereira, Afonso Arinos de Melo Franco também se projetaria como ensaísta e biógrafo, tendo exercido ativ idades políticas de modo corajoso e brilhante, brindando-nos depois com excelentes livros de memórias.Ele afirma que Gilberto Freyre entrou "de chofre na categoria dos Nabuco, dos Euclides da Cunha, dos Capistrano, dos grandes lidadores da inteligência brasileira e da compreensão do verdadeiro Brasil". Escreve que Casa-Grande \& Senzala é "uma das vigas-mestras do nosso edifício intelectual". Lamenta, entretanto: "a linguagem de Gilberto Freyre devia ter um pouco mais de dignidade". Não que ele, Afonso Arinos, fosse "um purista asmático e intransigente"; mas parecia-lhe que a língua "ch ula, impura e anedótica" de Gilberto Freyre tinha dado a CasaGrande \& Senzala "um aspecto literário que o seu assunto e as suas graves proporções não comportavam". ${ }^{13}$

\section{LÍNGUA E ESTILO DE GILBERTO FREYRE}

Não é difícil encontrar no livro o trecho que escandalizou o jovem Afonso Arinos de Melo Franco. Está no quinto e último c apítulo, no parágrafo em que o autor se refere à vida ociosa dos s enhores de engenho. Vale a pena reproduzi-lo, por vários motivos. Primeiro para que se perceba a reação de Afonso Arinos no ano já remoto de 1934. Segundo porque, como observou Álvaro Lins, já é 
tempo de julgar se Gilberto Freyre estava certo "na sua decisão de encher um livro da altura de Casa-Grande \& Senzala com certos termos que se pensam e se dizem, mas que não se escreviam até e ntão"14. E terceiro, last but not least, pela beleza do estilo freyriano: porque este parágrafo exemplifica o admirável recurso à enumeração whitmaniana e ao imagismo anglo-americano do início do século XX. Note-se, por exemplo, a bela imagem do senhor de engenho "deixando-se tirar de dentro de casa como geléia por uma c olher".

"Ociosa, mas alagada de preocupações sexuais, a vida do s enhor de engenho tornou-se uma vida de rede. Rede parada, com o senhor descansando, dormindo, cochilando. Rede andando, com o senhor em viagem ou a passeio debaixo de tapetes ou cortinas. Rede rangendo, com o senhor copulando dentro dela. Da rede não prec isava afastar-se o escravocrata para dar suas ordens aos negros; ma ndar escrever suas cartas pelo caixeiro ou pelo capelão; jogar gamão com algum parente ou compadre. De rede viajavam quase todos sem ânimo para montar a cavalo: deixando-se tirar de dentro de casa como geléia por uma colher. Depois do almoço, ou do jantar, era na rede que eles faziam longamente o quilo - palitando os dentes, fumando charuto, cuspindo no chão, arrotando alto, peidando, de ixando-se abanar, agradar e catar piolho pelas mulequinhas, coçando os pés ou a genitália; uns coçando-se por vício; outros por doença venérea ou da pele. Lindley diz que na Bahia viu pessoas de ambos os sexos deixando-se catar piolhos; e os homens coçando-se sempre de 'sarnas sifilíticas'."'15

Embora o verbo arrotar seja grosseiro e o verbo peidar seja chulo, sua utilização no parágrafo citado parece inevitável. Ridículo ficaria o autor se escrevesse que ao fazer o quilo na rede os senhores de engenho eructavam ou emitiam ventosidades. Ao comentar este parágrafo de Casa-Grande \& Senzala, o grande ensaísta e poeta David Mourão-Ferreira escreveu: "Quadro implacável: quadro mesmo terrível. Mas quadro que não pode nem deve fazer-nos e s- 
quecer, para lá da repulsa que o modelo nos provoque, a genial mestria do seu pintor". ${ }^{16}$

A conclusão que podemos tirar do episódio é que Gilberto Freyre estava certo e Afonso Arinos de Melo Franco - cinco anos mais moço - reagiu como um velho moralista à outrance. Embora os dois tivessem mantido, por toda a vida, um relacionamento cord ial, era visível a incompatibilidade de temperamentos e mesmo de cosmovisões. Foram ambos muito vaidosos. Gilberto Freyre ass umiu, na velhice, uma postura olímpica, goethiana que contrastava com a irreverência da mocidade. Tenho a impressão de que Afonso Arinos foi olímpico desde moço. Ele se considerava, intimamente, a maior figura da familia Melo Franco. Não deve ter apreciado, po rtanto, uma entrevista em que Gilberto Freyre sugeriu, como cand idata à Presidência da República, sua ilustre irmã, a senhora Maria do Carmo Nabuco.

Mais velho do que Afonso Arinos e Gilberto Freyre era o filólogo alagoano Mário Marroquim (1896-1975). Autor do lúcido ensaio A Língua do Nordeste, publicado em 1934 e reeditado em 1945 na coleção Brasiliana, Marroquim foi quem primeiro defendeu Gilberto Freyre da acusação de escrever em linguagem chula. Em seu artigo sobre Casa-Grande \& Senzala, publicado menos de dois meses depois do artigo de Afonso Arinos, ele escreveu: "Já houve crítico que o censurou pelos seus modismos e pela falta de 'certa dignidade' da sua linguagem. É o tabu da lingua portuguesa que ai n$\mathrm{da}$ faz mal assombrado nas nossas letras. É o bilingüismo literário teimando em conservar de pé fantasmas já desmoralizados; uma linguagem que não corresponde mais aos nossos meios de expre ssão. Gilberto Freyre sacudiu todas essas teias de aranha, arejou tudo, deixando que a sua linguagem escrita seja aquilo que na realidade é a nossa linguagem falada. Seu livro junta esse a todos os mais valores que representa. Com o senso exato da medida, não exagera nem deturpa: deixa que a frase flua com naturalidade, escorra espontânea, 
com todo o seu poder de expressão, sem perguntar primeiro aos gramáticos se era assim que Camões escrevia...". 17

A linguagem e o estilo de Gilberto Freyre continuaram atraindo a atenção dos estudiosos. Já citamos David MourãoFerreira, autor de três magistrais ensaios, hoje reunidos em seu livro Sob o Mesmo Tecto. Também foi citado Álvaro Lins, que ao apreciar, em 1941, o livro Região e Tradição, dedicou a Gilberto Freyre dois de seus rodapés semanais no Correio da Manhã, nos quais teceu sugestivas considerações sobre o assunto. ${ }^{18}$ Em 1954, o professor Moacir de Albuquerque conquistou uma das cátedras de Português do Instituto de Educação de Pernambuco com uma tese sobre A Linguagem de Gilberto Freyre. ${ }^{19}$ Desculpai a nota pessoal, mas não posso falar em Moacir de Albuquerque sem registrar ter sido ele quem, professor de Literatura brasileira no curso préjurídico, intimou-nos a ler Casa-Grande \& Senzala, para melhor entendermos o Brasil e, conseqüentemente, nossa literatura. Isto em 1940, quando estávamos no segundo ano da Guerra Mundial e no terceiro da Ditadura Vargas e a campanha contra Gilberto Freyre era comandada pelo jesuíta goês Antonio Ciriaco Fernandes e por parte do secretariado do então interventor federal em Pernambuco Ag amenon Magalhães.

Recorde-se que na obra coletiva Gilberto Freyre: sua Ciência, sua Filosofia, sua Arte, publicada em 1962, há duas contribuições importantes para o estudo do estilo freyriano: as de M. Cava lcanti Proença ${ }^{20}$ e de Otto Maria Carpeaux. A de Carpeaux é uma magistral exegese da "grande metáfora das palmeiras" no livro Sobrados e Mucambos. Disse Carpeaux que depois de ter lido aquela página a que dedicou seu ensaio, leu "muitas outras páginas, grandes páginas da prosa portuguesa; algumas iguais; nenhuma, superior". ${ }^{21}$ $\mathrm{O}$ estilo de Gilberto Freyre também foi estudado com erudição e sensibilidade pelo poeta e ensaísta César Leal. ${ }^{22}$ 


\section{VOLTANDO AOS ANOS 30}

Voltando aos anos 30, vale recordar que, em carta a Gilberto Freyre, Manuel Bandeira dava conta do grande sucesso de CasaGrande \& Senzala. Do insigne antropólogo ,educador e pioneiro da radiodifusão Roquette-Pinto dizia o seguinte: "O Roquette ta mbém está no auge da admiração. Recebeu o livro há três dias e ontem à noite, na hora educativa da Rádio-Sociedade, encheu todo o tempo falando do livro, classificando-o de obra monumental. Eu e o Rodr igo ficamos inconsoláveis de ter perdido isso. Quem nos informou foi o Cruls. Disse o Roquette que à parte qualquer outro valor da obra, só a bibliografia que você reuniu representa uma contribuição inestimável. Fez grandes elogios às suas opiniões sobre miscigen ação. Não esqueceu a linguagem e leu trechos inteiros do livro". ${ }^{23}$ Roquette-Pinto expandiu sua fala radiofônica em artigo publicado pelo Boletim de Ariel e por $\mathbf{O}$ Jornal. Ele concluiu seu artigo dizendo: "No que se refere a índios, o livro de Gilberto Freyre vale por uma biblioteca". 24

\section{DIÁLOGO COM A CRÍTICA}

Não é o que pensam alguns antropólogos brasileiros de no ssos dias. Mesmo na época foram ouvidas vozes discordantes, tanto em relação a índios como a negros e portugueses. Gilberto Freyre sempre foi acusado ora de negrófilo, ora de ter uma visão do terraço das casas-grandes; ora de lusófilo, ora de lusófobo. Ele bem podia ter clamado como Gide: "por favor, não me compreendam tão d epressa". E foi recebendo todas as críticas com interesse. No prefácio à segunda edição de Casa-Grande \& Senzala, datado de 1934, informa que aproveitou, em notas e mesmo no texto, "não só reparos de críticos, feitos à primeira edição, como sugestões de novas leituras e de pesquisas mais recentes do Autor". ${ }^{25}$ 
Em artigo publicado pelo Boletim de Ariel de maio de 1935 ele continua o diálogo com a crítica, iniciado no referido prefácio à segunda edição e continuado nos prefácios às edições subseqüentes. ${ }^{26}$ Como a terceira edição, de 1938, foi publicada à sua revelia, escreveu um artigo no qual comenta críticas e discussões suscitadas pela segunda edição. Afirma que sempre esperou por críticas e s ugestões. E responde serenamente a todas. ${ }^{27}$

O contrato com o editor Schmidt dava-lhe o direito de edição por 10 anos. Por isso, somente em 1943 apareceu a quarta edição, em dois volumes, com as notas de rodapé transferidas para o fim de cada capítulo. A esta edição, muito bem cuidada, deu José Olympio o título de definitiva, como que enfatizando o desgosto do autor com as edições anteriores. Mas logo no primeiro parágrafo do pref ácio à quarta edição Gilberto Freyre faz uma advertência que consid ero da maior relevância, pois contém uma autocrítica e revela uma humildade surpreendente em autor confessadamente vaidoso: diz que a edição é definitiva "dentro da relatividade que condiciona um ensaio da natureza deste, cuja objetividade depende, em grande pa rte, de novos avanços nas várias ciências e estudos em que se baseia. Isto sem falar nos aspectos, porventura ainda mais flutuantes, de sua subjetividade. As idéias e atitudes do Autor. Seus pontos de vista. Os personalismos em que às vezes se alongam suas interpretações". ${ }^{28}$

Vê-se que a "instância prefacial" - para usar a expressão de Gerard Genette - foi o recurso adotado por Gilberto Freyre para dialogar com os leitores em geral e a crítica em particular. Antig amente ninguém dava importância aos prefácios. Havia até quem se gabasse de não os ler. Hoje eles são estudados pelos teóricos da lit eratura e classificados como para-textos. ${ }^{29}$ Os prefácios de CasaGrande \& Senzala foram estudados por Ria Lemaire, da Universidade de Poitiers. ${ }^{30}$ Mas quem primeiro salientou sua importância foi Álvaro Lins nos já citados rodapés de 1941. ${ }^{31}$ 
Entretanto, a partir da 16a edição, de 1973, o autor concordou com o editor em substituir os prefácios da segunda e subseqüentes edições por um resumo no qual repete seu propósito de dialogar com o público, os críticos e os intelectuais "que tenham confirmado ou discutido suas antecipações - algumas recebidas de início (...) como escandalosamente heréticas em ciência e em saber, em met odologia e na própria expressão literária". 32

Gilberto Freyre não devia ter concordado com tal substitu ição, pois ele próprio reconhecia a importância dos seus prefácios para a história e a sociologia do livro: "a história e a sociologia das relações de um autor com diferentes públicos e com sucessivas ger ações de leitores". ${ }^{33}$

Como também não devia ter concordado com os cortes e condensações do professor Rod Horton ao traduzir Ordem e Progresso para o inglês. Pois um desses cortes foi o do capítulo mais sugestivo da obra, que é a "tentativa de síntese" na qual se enco ntram algumas das páginas mais representativas do estilo enumerativo do autor, com os mais longos parágrafos do ensaísmo lusobrasileiro: parágrafos somente comparáveis aos da ficção de Proust e de Joyce. ${ }^{34}$

Já que me referi à "instância prefacial", gostaria de falar ainda a respeito dos chamados por Gerard Genette de prefácios alógrafos (allographes). São assim designados os prefácios assinados não pelos autores dos livros e sim por outros autores. Também sob este a specto a fortuna crítica de Gilberto Freyre é muito rica, não cabendo, por isso, nos limites razoáveis de uma conferência. Tenho, portanto, de concluir e vou faze-lo referindo-me a um aspecto muito original da recepção da obra de Gilberto Freyre. 


\section{CONSAGRAÇÃO POÉTICA}

O que eu sempre me pergunto - estendendo agora a pergunta aos melhor informados - é se existe outra obra ensaística, em qua lquer língua, que tenha inspirado poemas como a de Gilberto Freyre inspirou os de poetas do altíssimo nível de Manuel Bandeira, Carlos Drummond de Andrade e João Cabral de Melo Neto. O de Bandeira foi o primeiro e é uma obra-prima de lirismo, erudição e sense-ofhumour. Foi escrito em 1934, ainda sob o impacto da publicação de Casa-Grande \& Senzala, e publicado na edição especial de um jornal mineiro. E só reapareceu na edição príncipe do seu livro $\mathrm{M}$ afuá do Malungo, impressa em Barcelona por João Cabral de Melo Neto. ${ }^{35}$

Somente um poeta genial conseguiria resumir em 10 estrofes um livro de mais de 500 páginas, mencionando o arianismo de G obineau e de Oliveira Viana, o culturalismo de Franz Boas, as relações raciais, a mancha mongólica chamada popularmente de genipapo, a lascívia do colonizador, e até, por elipse, a "tristeza brasileira" de Paulo Prado:

\section{CASA-GRANDE \& SENZALA}

Casa-Grande E Senzala,

Grande livro que fala

Desta nossa leseira

Brasileira.

Más com aquele forte

Cheiro e sabor do Norte

- Dos engenhos de cana

22
Que importa? É lá desgraça?

Essa história de raça,

Raças más, raças boas

-Diz o Boas -

É coisa que passou

Com o franciú Gobineau.

Pois o mal do mestiço

Não está nisso. 
Com fuxicos danados

E chamegos safados

De mulecas fulôs

Com sinhôs.

A mania ariana

Do Oliveira Viana

Leva aqui a sua lambada

Bem puxada.

Se nos Brasis abunda

Jenipapo na bunda,

Se somos todos uns

Octoruns,
Está em causas sociais,

De higiene e outras que tais:

Assim pensa, assim fala

\section{Casa-Grande E Senzala.}

Livro que à ciência alia

A profunda poesia

Que o passado revoca

E nos toca

A alma de brasileiro

Que o portuga femeeiro

Fez e o mal fado quis

Infeliz!

O de Carlos Drummond de Andrade apareceu em 1955: em seu livro Viola de Bolso Novamente Encordoada. É outra síntese admirável, como só os poetas sabem fazer, não apenas de CasaGrande \& Senzala, mas de toda a obra de Gilberto Freyre. São três estrofes de quatro versos, rimados os primeiros com os terceiros e os segundos com os quartos. ${ }^{36}$

\footnotetext{
A Gilberto Freyre

Velhos retratos; receitas

de carurus e guisados;

as tortas Ruas Direitas;

os esplendores passados;

A linha negra do leite

coagulando-se em doçura;

as rezas à luz do azeite;

o sexo na cama escura;
} 
A casa-grande; a senzala;

inda os remorsos mais vivos,

tudo ressurge e me fala,

grande Gilberto, em teus livros.

Quando Casa-Grande \& Senzala completou quarenta anos, João Cabral de Melo Neto celebrou o livro num poema curto e de grande força expressiva. Foi uma espécie de reconciliação com o primo a quem dera umas alfinetadas em $O$ Cão Sem Plumas e $\mathbf{O}$ Rio. ${ }^{37}$

Em carta de 1940 a Carlos Drummond de Andrade, divulg ada recentemente por Mário Hélio, Cabral se queixa de Freyre que, como ditador cultural de Pernambuco, estaria sabotando o Congre sso de Poesia que ele, Willy Lewin e Vicente do Rego Monteiro est avam então promovendo no Recife. A sabotagem consistiria na decl aração atribuída a Freyre de que aquele não era o momento apropri ado para a poesia. Estávamos, de fato, no segundo ano da Guerra Mundial, com a Alemanha invadindo os paises europeus e castiga ndo a Inglaterra. Se os Aliados perdessem a guerra Gilberto Freyre iria certamente para um campo de concentração, pois teve a coragem de desmitificar o arianismo exatamente no ano em que Hitler chegava ao poder. Estranhei a queixa de Cabral porque um dos assuntos que tratei com Freyre, ao ser-lhe apresentado em 1941, foi o Congresso de Poesia, do qual participei com uma comunicação sobre a poesia em sua obra.

Para caracterizar a linguagem de Freyre, Cabral fala de redes, alpendres, mestiçagem, sesta e preguiça:

\section{CASA-GRANDE \& SENZALA: QUARENTA ANOS}

Ninguém escreveu em português

no brasileiro de sua língua: 
dos alpendres, da alma mestiça,

medindo sua prosa de sesta,

ou prosa de quem se espreguiça.

\section{CONCLUSÃO}

Depois de Casa-Grande \& Senzala a historiografia brasileira não podia mais ser a mesma narração monótona de episódios esp etaculares. A obra de Gilberto Freyre representou, como assinalou José Honório Rodrigues, "um caminho novo na historiografia". 38 Com ela veio o conceito de tempo psicológico e sociológico, veio a história íntima e a das mentalidades, o pluralismo metodológico e a interdisciplinaridade, a utilização de fontes até então desprezadas, como a história oral, os anúncios de jornais, as teses médicas, os a rquivos paroquiais, os assentamentos de familias.

O primeiro fruto dessa revolução historiográfica foi o apar ecimento, três anos depois, do livro de Sérgio Buarque de Holanda Raizes do Brasil, por isso mesmo acolhido por Gilberto Freyre como primeiro volume da Coleção Documentos Brasileiros, que dirigia na Livraria José Olympio Editora. ${ }^{39} \mathrm{O}$ que podemos dizer, em conclusão, é que a Gilberto Freyre não faltou a compreensão e o louvor da crítica mais esclarecida, tanto no Brasil como no estrange iro. A obra de Gilberto Freyre foi como a semente da parábola eva ngélica: não caiu à beira do caminho ou sobre a pedra, para ser esqu ecida; nem sobre espinhos, para ser sufocada; caiu em boa terra e deu "fruto com perseverança" (Lucas 8: 11-15). 


\section{Referências Bibliográficas}

1 FREYRE, Gilberto. Sociologia, psicologia e psiquiatria. Recife: Officinas do Diário da Manhã, 1941. Conferência de 1940 reproduzida no livro Problemas Brasileiros de Antropologia. 14a ed. Rio de Janeiro: José Olympio, 1973.

2 FREYRE, Gilberto. "Sugestòes do Rio". Diário de Pernambuco (Recife) 25 de março de 1926. Artigo reproduzido no livro Tempo de Aprendiz. Sào Paulo: IBRASA, 19979, v. II, p. 275-2276.

3 FREYRE, Gilberto. Guia pratico, histórico e sentimental da cidade do Recife. Recife: Ed. do Autor, 1934. Olinda: $2^{\circ}$ guia pratico, histórica e sentimental de cidade brasileira. Recife: Ed. do Autor, 1939.

4 FREYRE, Gilberto. “ O Rio de Janeiro que Gastão Cruls vê". In: Cruls, Gastão. Aparência do Rio de Janeiro. Rio de Janeiro: José Olympio, 1949, v. 1, p. 13-17.

5 FONSECA, Edson Nery da. "A fortuna crítica de Gilberto Freyre". Revista da Academia Pernambucana de Letras (Recife) n ${ }^{\circ} 29$, p. 51-55, maio /junho 1980. Casa-Grande \& Senzala e a crítica brasileira de 1933 a 1944. Recife: Companhia Editora de Pernambuco, 1985.

6 FREYRE, Gilberto. Insurgências e ressurgências atuais. Rio de Janeiro: Editora Globo, 1983.

7 BOSI, Alfredo. História concisa da literatura brasileira. São Paulo: Cultrix, 1988, p. 355-357.

8 LINS, Álvaro. "Clássico e moderno". Correio da Manhã (Rio de Janeiro) 28 de novembro de 1942 e 20 de fevereiro de 1943. Artigos reproduzidos em seu livro Jomal de crítica, $3^{3}$ série, Rio de Janeiro: José Olympio, 1944, p. 126-138.

9 RIBEIRO, João. “Casa-Grande \& Senzala”. Jomal do Brasil (Rio de Janeiro) 31 de janeiro de 1934. Artigo reproduzido na obra póstuma organizada por Múcio Leão Crítica v. IX: Os modernos. Rio de janeiro: Academia Brasileira de Letras, 1952, p. 274-277 e na coletânea organizada por Edson Nery da Fonseca Casa-Grande \& Senzala e a crítica brasileira de 1933 a 1944, op. cit. (referência $\left.n^{\circ} 5\right)$, p. $75-78$. 
10 GRIECO, Agripino. "Casa-Grande \& Senzala". O Jornal (Rio de Janeiro) 28 de janeiro de 1934. Artigo reproduzido pelo autor em suas obras Gente nova do Brasil (Rio de Janeiro: José Olympio, 1935) e Poetas e prosadores do Brasil (Rio de Janeiro: Conquista, 1968) e na coletânea organizada por Edson Nery da Fonseca Casa-Grande \& Senzala e a crítica brasileira de 1933 a 1944, op. cit. (referência $\mathrm{n}^{\circ}$ 5), p. 61-74.

11 BARRETO, Plínio, "Livros Novos". O Estado de S. Paulo, 3 de março de 1934. Artigo reproduzido por Edson Nery da Fonseca na coletânea CasaGrande \& Senzala e a crítica brasileira de 1933 a 1944, op. cit. (referência $\mathrm{n}^{\circ}$ 5), p. 133-135.

12 PEREIRA, Lúcia Miguel. "Casa-Grande \& Senzala”. Gazeta de Notícias (Rio de Janeiro) 7 de outubro de 1934. Artigo reproduzido por Edson Nery da Fonseca na coletânea Casa-Grande \& Senzala e a crítica brasileira de 1933 a 1944, op. Cit. (referência n ${ }^{\circ}$ 5), p. 133-135.

13 MELO FRANCO, Afonso Arinos de. "Casa-Grande \& Senzala". O Jornal (Rio de Janeiro) 15 de fevereiro de 1934. Artigo reproduzido pelo autor em seu livro Espelho de três faces (São Paulo: Ed. do Brasil, 1937 e por Edson Nery da Fonseca na coletânea Casa-Grande \& Senzala e a crítica brasileira de 1933 a 1944, op. Cit. (referência ${ }^{\circ}$ 5) p. 81-88.

14 LINS, Álvaro. "Regiào e Tradição". Correio da Manhã (Rio de Janeiro) 5 e 12 de julho de 1941. Artigos reproduzidos pelo autor em seu livro Jornal de crítica, segunda série. (Rio de Janeiro: José Olympio, 1943, p. 202-222) e por Edson Nery da Fonseca na coletânea "Gilberto Freyre ano 80", Ciência \& Trópico (Recife) v. 8, nº 1, p. 29-40, janeiro/junho 1980.

15 FREYRE, Gilberto. Casa-grande \& senzala. Rio de Janeiro: Maia \& Schmidt, 1933, p. 467-468.

16 MOURÃO-FERREIRA, David. "Casa-Grande \& Senzala como obra literária". Em seu livro Sob o mesmo tecto. Lisboa: Editorial Presença, 1989, p. 169 181.

17 MARROQUIM, Mário. "Casa-Grande \& Senzala". Artigo publicado em 1 de abril de 1934 (recorte sem indicação do título da publicação) e reproduzido por 
Edson Nery da Fonseca na coletânea Casa-Grande \& Senzala e a crítica brasileira de 1933 a 1944, op. cit. (referência $n^{\circ}$ 5) p. 109-112.

18 LINS, Álvaro. "Regiào e Tradição". Artigos citados (referência n 14)

19 ALBUQUERQUE, Moacir Borges de. Linguagem de Gilberto Freyre.

Reedição da tese do concurso para provimento efetivo de uma das cadeiras de Português do Insti tuto de Educaçào de Pernambuco, apresentada em 1954. Recife: Conselho Estadual de Cultura, 1981.

20 PROENÇA, M. Cavancanti. “Gilberto Freyre: uma interpretaçào do seu estilo". In: Amado, Gilberto et alii. Gilberto Freyre: sua ciência, sua filosofia, sua arte. Rio de Janeiro: José Olympio, 1962, p. 158-165.

21 CARPEAUX, Otto Maria. "Uma página de Gilberto Freyre". In: Amado, Gilberto et alii. Gilberto Freyre: sua ciência, sua filosofia, sua arte, op. cit. (referência $\mathrm{n}^{\circ} 20$ ).

22 LEAL, César."A imagem visual na expressão literária em Gilberto Freyre”. In: Accioly, Marcus et alii. Expressão literária em Gilberto Freyre. Recife: Conselho Estadual de Cultura, 1981, p. 43-65. Ver também prefácio do autor à obra póstuma de Gilberto Freyre a ser editada em 2000 Três histórias mais ou menos inventadas.

23 BANDEIRA, Manuel. Carta a Gilberto Freyre, de 10 de janeiro de 1934. Reproduzida em seu livro Poesia e Prosa. Rio de Janeiro: José Aguilar, 1958, v. II, p. 1407.

24 ROQUETTE-PINTO, E. "Casa-Grande \& Senzala". Boletim de Ariel (Rio de Janeiro) $\mathrm{n}^{\circ}$ 5, p. 116, fevereiro de 1934 e O Jornal (Rio de Janeiro) 18 de fevereiro de 1934. Artigo reproduzido por Edson Nery da Fonseca na coletânea Casa-Grande \& Senzala e a crítica brasileira de 1933 a 1944, op. cit. (referência $\mathrm{n}^{\circ} 5$ ), p. 89-91.

25 FREYRE, Gilberto. Casa-grande \& senzala. $2^{a}$ ed. Rio de Janeiro: SchmidtEditor, 1936.

26 FREYRE, Gilberto. "Pontos em certos ii". Boletim de Ariel (Rio de Janeiro) $\mathrm{n}^{\circ} 8$, p. 216-217, maio de 1935. Artigo reproduzido por Edson Nery da Fonseca na coletânea Casa-Grande \& Senzala e a crítica brasileira de 1933 a 1944, op. cit. (referência $\mathrm{n}^{\circ}$ 5), p. 301-305. 
27 FREYRE, Gilberto. "A propósito de um livro em $3^{\text {a }}$ edição". Revista do Brasil (Rio de Janeiro) 3a fase, $n^{\circ} 1$, p. 33-40, julho de 1938. Artigo incluído em Casa-Grande \& Senzala a partir da $4^{a}$ ed. (Rio de Janeiro: José Olympio, 1943) como "Quase um prefácio à 3a ediçâo".

28 FREYRE, Gilberto. Casa-Grande \& Senzala. $4^{a}$ ed. definitiva. Rio de Janeiro: José Olympio, 1943.

29 GENETTE, Gérard . Seuils. Paris: Seuil, 1987.

30 LEMAIRE, Ria. "Héros littéraire et historien: chemins croisés dans les préfaces de Casa-Grande e Senzala de Gilberto Freyre". Paris: Presses de l'Université de Paris-Sorbonne. Centre d'Études sur le Brésil.Littérature/Histoire: regards croisés)

31 LINS, Álvaro. "Região e Tradição". Artigo citado (referência n o 14)

32 FREYRE, Gilberto. Casa-grande \& senzala. $16^{\mathrm{a}}$ ed. Rio de Janeiro: José Olympio, 1973.

33 FREYRE, Gilberto. Casa-grande \& senzala. $16^{\mathrm{a}}$ ed. cit.

34 FREYRE, Gilberto. Order and progress; Brazil from Monarchy to Republic. Edited and translated by Rod W. Horton. New York: Alfred A. Knopf, 1970.

35 BANDEIRA, Manuel. Mafuá do malungo. Barcelona: O Livro Inconsútil, 1948.

36 ANDRADE, Carlos Drummond de Andrade. Viola de bolso novamente encordoada. Rio de Janeiro: José Olympio, 1955.

37 MELO NETO, João Cabral de. Poesia crítica. Rio de Janeiro: José Olympio, 1982 , p. 60.

38 RODRIGUES, José Honório. "Casa-Grande \& Senzala: um caminho novo na historiografia”. In: Amado, Gilberto et alii. Gilberto Freyre: sua ciência, sua filosofia, sua arte, op. cit. (referência $\mathrm{n}^{\circ} 20$ ), p. 434-441.

39 HOLANDA, Sérgio Buarque de. Raizes do Brasil. Rio de Janeiro: José Olympio, 1936 (Coleçâo Documentos Brasileiros, 1) 